\title{
DUST STORM CONTRIBUTIONS TO AIRBORNE PARTICULATE MATTER IN REYKJAVÍK, ICELAND
}

\author{
THROSTUR THORSTEINSSON ${ }^{1, *}$, GUĐRÚN GÍSLADÓTTIR ${ }^{1,2}$, JOANNA BULLARD $^{3}$ \\ and GRANT McTAINSH ${ }^{4}$
}

\begin{abstract}
${ }^{1}$ Institute of Earth Sciences, University of Iceland, Sturlugata 7, 101 Reykjavík, Iceland;
${ }^{2}$ Department of Life- and Environmental Science, University of Iceland; ${ }^{3}$ Polar and Alpine

Research Centre, Department of Geography, Loughborough University, LE11 3TU UK; ${ }^{4}$ Atmospheric Environment Centre, Griffith School of Environment, Griffith University, Brisbane, Qld. 4111, Australia;
\end{abstract}

(*corresponding author, e-mail: ThrosturTh@gmail.com, tel: +354-525-4940,fax: +354-562-9767)

\begin{abstract}
Episodes of high levels of particulate matter (PM) in Reykjavík occur several times a year. The main sources of daily variation in PM are traffic or highly localized (e.g. construction) sources, however several episodes have been identified where these are not the cause. Examining $\mathrm{PM}_{10}$ (diameter $<10 \mu \mathrm{m}$ ) levels around the time when dust storms are seen on satellite images, and verifying that the weather conditions are favorable for the duration of the high levels of PM (>50 $100 \mu \mathrm{g} \mathrm{m}^{-3}$; 30-min average), demonstrates that dust storms are the source of these increased levels of $\mathrm{PM}_{10}$. Since satellite coverage is sparse, visual confirmation of many such peaks in $\mathrm{PM}_{10}$ cannot be achieved. The level of pollution measured in Reykjavík during dust storms indicates that at least $200 \mathrm{~kg} \mathrm{~s}^{-1}$ of $\mathrm{PM}_{10}$ sized material is being eroded and transported away from sand plains $\sim 110 \mathrm{~km}$ away - this equates to an emission rate of $35 \mathrm{~g} \mathrm{~m}^{2} \mathrm{hr}^{-1}$. The source regions for dust storms in Iceland are the sandur areas on the southern coast of Iceland, and regions close to the glaciers. With climate warming, and fast retreating glaciers, the potential source regions in Iceland are rapidly increasing.
\end{abstract}

Keywords: Particulate matter, Air pollution, Climate, Sandstorms, Iceland. 


\section{Introduction}

Small particles $(<10 \mu \mathrm{m}$ in diameter) play an important role in the earth-atmosphere-ocean system and have been shown to have an impact on soils (both where eroded and where deposited), atmospheric and climatic processes and marine systems as well as on health, travel (in particular road and air) and infrastructure (Chan et al. 2005; Jickells et al., 2005; Krzyzanowski et al., 2005; McTainsh and Strong, 2007). Particulate matter (or aerosols) includes solid and liquid particles suspended in the atmosphere and can be derived from both natural and anthropogenic sources such as windblown dust, sea salts, volcanic ash, smoke from fires and pollution from traffic and industrial emissions. Natural aerosols are generally (but not always) larger particles than anthropogenic aerosols. Here large is used to refer to particles with a diameter of $\leq 10 \mu \mathrm{m}\left(\mathrm{PM}_{10}\right)$ and small for diameters $\leq 2.5 \mu \mathrm{m}\left(\mathrm{PM}_{2.5}\right)$; using this definition, $\mathrm{PM}_{10}$ includes $\mathrm{PM}_{2.5}$. The relative importance of different sources of particulate matter varies at global, regional and local scales, and seasonally. Dust storms contribute substantially to $\mathrm{PM}_{10}$ concentrations in many regions of the world. The world's major dust source region is the Sahara accounting for about half the global dust emissions, and other important regions are generally arid, and large basins with internal drainage (Prospero et al., 2002; Griffin and Kellogg, 2004; Goudie, 2009). Estimates of the total global emission of $\mathrm{PM}_{10}$ material vary between 1000 - $2000 \mathrm{Tg} \mathrm{yr}^{-1}$ ( Tegen et al., 2004; Tanaka and Chiba, 2006). The concentration of aerosols in a dust storm can exceed $6000 \mu \mathrm{m} \mathrm{m}^{-3}$ and particles can be carried tens to thousands of kilometers from source (Song et al., 2007).

Over the past few years, therefore, considerable effort has been put in to achieving a better understanding of dust emissions, transport and deposition. These investigations have included fieldbased studies, but have also drawn heavily upon satellite data which have been used effectively to identify dust sources and dust transport paths, both at the global scale and for individual dust storm events (e.g. Baddock et al., 2009; Prospero et al., 2002; Schepanski et al., 2007). Most of this research has been focused on the prominent global dust sources in the subtropics, however significant dust events also occur in higher latitudes, particularly in pro-glacial and paraglacial regions (Ballentyne, 2002; Prospero et al., 2008). These include Alaska (Hope et al., 1991; Crucius et al., 2011), Greenland (Dijkmans and Törnqvist, 1991; Bullard and Austin, 2011), Iceland (Arnalds et al., 2001, Arnalds, 2010), northern Canada (Nickling, 1978), New Zealand (Marx and McGowan, 2005; Wang and Shooter, 2005) and southern Patagonia (Gassó and Stein, 2007). The focus of this paper is dust storms in southern Iceland. 


\subsection{AEOLIAN ACTIVITY IN ICELAND}

Sandy deserts with active aeolian processes cover at least $20000 \mathrm{~km}^{2}(\sim 20 \%)$ of Iceland (Arnalds et al., 2001) and their distribution is closely associated with the island's icecaps, the active volcanic systems and eroded soils (Arnalds, 2010). Glaciers are very efficient producers of fine particles, less than $2000 \mu \mathrm{m}$, due to the grinding action of ice over subglacial sediments and bedrock, and these are transported beyond the ice in meltwater as suspended sediments. In general, meltwater suspended sediment concentration is very variable both seasonally within a single sub-glacial catchment (Hodson and Ferguson, 1999; Bullard and Austin, 2011) and from region to region depending on glacier dynamics, thermal regime and geology (Orwin et al., 2010). Such spatial and temporal variability makes it difficult to obtain representative values, but suspended sediment

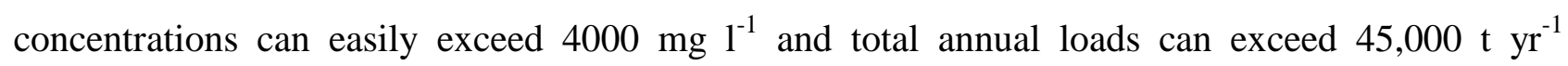
(summarized in Orwin et al., 2010). Although some of this load will be transported directly by rivers to the oceans, large meltwater flood events can deposit thick layers of fine sediment across proglacial floodplains (known as sandur in Iceland). Icelandic glaciers are warm-based and dynamic and all the major ice caps feature surge-type glaciers (Björnsson and Pálsson, 2008). Meltwater sediment concentrations, particular the fine sediment component, increases during surges and is also often elevated during glacier-related floods (jökulhlaups) (Sigurðsson, 1998; Pálsson et al., 2000). A lack of vegetation and strong winds cause the aeolian redistribution of these sediments (Dugmore et al., 2009; Guðbergsson, 1996), and whilst the coarser sand-sized particles are typically retained around the margins of the icecaps (Gisladottir et al., 2005), the finer material, including $\mathrm{PM}_{10}$, can be transported greater distances as dust plumes which are visible on satellite imagery (Ovadnevaite et al., 2009). A survey of weather station data, news reports and satellite images indicates that there were 35 days in 2007 and 28 days in 2008 where dust storm activity was recorded in Iceland (Georgsdóttir personal communication December 2009).

\section{$<$ Figure 1>}

Wind also has had a major impact on soil development in Iceland and preserved soils have therefore archived aeolian activities. During periods of intense aeolian activity local redistribution of soils and sediment have resulted in coarser soil texture (Ólafsdóttir and Guðmundsson, 2002; Jackson et al., 2005; Dugmore at al., 2009; Gísladóttir et al., 2010) - this is because soils have lost their fine material and light particles such as soil organic carbon, which have been transported off-shore in large quantities (Óskarsson et al., 2004; Gísladóttir et al., 2010), or into sediment traps such as lakes 
(Gathorn-Hardy et. al., 2009; Geirsdóttir et al., 2009).

The areas of active aeolian activity in Iceland receive precipitation ranging from $<400 \mathrm{~mm}$ rainfall per year (semi-arid) to $>2000 \mathrm{~mm}$ per year (very humid) (Arnalds et al., 2001). Dust storms generally occur when weather is, or has been, dry (Gisladottir et al., 2005) and the threshold wind speed for entrainment (measured at 2 m elevation) for Icelandic sand surfaces ranges from 5-10 $\mathrm{m} \mathrm{s}^{-}$

${ }^{1}$ depending on surface roughness (Arnalds et al., 2001; Gisladottir et al., 2005).

In some remote high latitude regions dust storms have little direct anthropogenic impact, however, in others they may have a significant effect on air quality in populated regions. For example, high levels of particulate matter are commonly recorded in Reykjavík, the capital city of Iceland. Although some of this can be attributed to the accumulation of traffic pollution, especially under still conditions, or to construction site activity within the city (Jóhannsson, 2007), there are often days when aerosol concentration is high but cannot be attributed to these factors.

The aim of this paper is to examine three episodes when high particulate concentrations were recorded in Reykjavík in 2007 and 2008 to determine whether dust storms elsewhere in Iceland could have been the cause. Using a combination of satellite imagery, air parcel trajectory analyses and meteorological data the dust sources are identified and their dust source strengths are modeled.

\section{Methods}

\subsection{MeteorologicAl ANd PM 10 DATA}

Data from weather stations in Vestmannaeyjar (STO) and Pykkvibær (PYK), along with weather information from the stations in Reykjavík, are used in this paper (Fig. 1). The STO station is a manned station which has been operated since 1921 and is located at $64.4^{\circ} \mathrm{N}$ and $20.288^{\circ} \mathrm{E}$, and an elevation of 118 m.a.s.l. The PYK station is an automated station in operation since 1996, located at $63.748^{\circ} \mathrm{N}$ and $20.618^{\circ} \mathrm{E}$, and elevation of 10 m.a.s.l.

Two permanent stations, GRE and FHG (about $1 \mathrm{~km}$ apart; Fig. 1), have measured $\mathrm{PM}_{10}$ concentration in Reykjavík continuously since 2002. The GRE station is equipped with Thermo EMS Andersen FH 62 I-R instruments, and the FHG station is equipped with Eberline Instrument Gmbh instrument (Böðvarsdóttir, 2007). They also record data on weather conditions, and several other air pollutants (Böðvarsdóttir, 2007). There is also a recently established station, HEH, in Hafnafjörður, approximately $10 \mathrm{~km} \mathrm{SSW}$ of GRE and FHG, within the greater Reykjavík area, which also measures $\mathrm{PM}_{10}$ concentration (instruments include Thermo 5030/42i/450i). The $\mathrm{PM}_{10}$ 
levels used below to examine the dust storm peaks come from these three (GRE, FHG and HEH) stations. There are no permanent measuring stations for PM pollution outside the greater Reykjavík area in Iceland, so information about remote sources of PM has to be obtained indirectly.

\subsection{SATELLITE DATA AND AIR PARCEL TRAJECTORY ANALYSES}

Satellite data come from the Moderate-resolution Imaging Spectroradiometer, or MODIS, which is one of four sensors carried on-board NASA's first Earth Observing System (EOS) satellite 'Terra', which was launched in December 1999. Another MODIS sensor was launched on the second EOS satellite 'Aqua' in May 2002. Images from the MODIS sensor are available through the MODIS Rapid Response System and are used to provide visual evidence for the source of dust storms reaching the measurement stations in Reykjavík. The Terra and Aqua satellites provide images of Iceland around $1330 \mathrm{~h}$ and $1350 \mathrm{~h}$, respectively (the time when Iceland is close to the center of the field of view), thus the temporal resolution is sparse. Overcast skies are also quite common in Iceland, resulting in further reduction of possible observations of dust storm events.

Air parcel trajectory modeling using the HYSPLIT (HYbrid Single-Particle Lagrangian Integrated Trajectory) model, developed by the National Oceanic and Atmospheric Administration (NOAA), has been demonstrated a useful tool for identifying dust sources (Borge et al., 2007; Karaca et al., 2009; McGowan and Clark, 2008; Rivera et al., 2009). The online version of the HYSPLIT model (Draxler and Rolph, 2010) was used to model both forward and backward trajectories.

\section{Description of the dust events}

The $\mathrm{PM}_{10}$ pollution in Reykjavík is generally low; the annual level is around $22 \mu \mathrm{g} \mathrm{m}^{-3}$ (Fig. 2). However, throughout the year the level of $\mathrm{PM}_{10}$ pollution is characterized by sharp, short duration, peaks in concentration. The daily health limit for $\mathrm{PM}_{10}$ pollution in Iceland is $50 \mu \mathrm{g} \mathrm{m}^{-3}$, and according to health regulations it should not exceed that more than 7 times in 2010 (12 times was permitted in 2009). In recent years the daily health limit has been exceeded, at GRE, 20 times in 2009, 19 times in 2008, 17 times in 2007, and 29 times in 2006. 
$<$ Figure 2>

The sources responsible for the $\mathrm{PM}_{10}$ health limit being exceed in 2008 have been analyzed by the City of Reykjavík (personal communication with A R Böðvarsdottir). According to their definition local sources and dust storms contribute to approximately $1 / 3$ of those days each, while traffic and remote sources contribute to $1 / 6$ of those days each (Fig. 3). Local sources refer to PM during windy conditions, when high levels are only recorded at a single site and not recorded at other stations in Reykjavík. Some of these might be due to dust storms as local variations could in some cases explain the different levels. Remote sources refer to pollution from Europe, such as seen from PROMOTE IAQ ${ }^{1}$ (PROtocol MOniToring Integrated Air Quality) data. Traffic in Reykjavík has strong peaks in the morning and afternoon, and high levels of PM due to traffic mainly occur when the air is still.

Figure 4 shows hourly variation in $\mathrm{PM}_{10}$ concentration, wind direction and wind speed for six days during 2008 when dust storms caused $\mathrm{PM}_{10}>50 \mu \mathrm{g} \mathrm{m}^{-3}$. The wind direction is typically ESE at $119^{\circ} \pm 15^{\circ}$ and the wind speed $7 \pm 2 \mathrm{~m} \mathrm{~s}^{-1}$ (Fig. 4). $\mathrm{PM}_{10}$ concentrations are generally lower during the night and early morning and increase in the afternoon. It is not entirely clear what drives this diurnal cycle, and an exploration of this is beyond the scope of this paper, however it may be linked to diurnal patterns of local sand transport at the dust sources (Stout, 2010) or local weather patterns at source causing fluctuations in soil moisture availability (Wiggs et al., 2004). The three events considered below, one from 2007 and two from 2008, are chosen because they represent events where high $\mathrm{PM}_{10}$ concentration in Reykjavík is measured, unrelated to traffic or local sources, and there are clear satellite images showing the source area.

$<$ Figure 3>

$<$ Figure 4>

\subsection{DUST STORM ON APRIL 28, 2007}

On April 28, 2007, a large peak in $\mathrm{PM}_{10}$ pollution was measured at both GRE and FHG stations (Fig. 5). The concentration the day before and after at FHG was normal, that is, much lower, with peak values around $50 \mu \mathrm{g} \mathrm{m}^{-3}$ which was typical for the FHG station in 2007.

\footnotetext{
${ }^{1}$ IAQ website: http://wdc.dlr.de/data_products/projects/promote/IAQ
} 
The MODIS Aqua satellite image captured at 13:45 UTC (local time) on the same day as this event clearly shows dust blowing from Landeyjasandur and Markarfljót towards Reykjavík (Figure 5d).

Landeyjasandur covers about $60 \mathrm{~km}^{2}$ area and is located $\sim 114 \mathrm{~km}$ from Reykjavík on a bearing of $\sim 125^{\circ}$ from N. The wind-speed and direction agree well with the visual evidence (Fig. 5). The PYK station is located $\sim 30 \mathrm{~km}$ from Landeyjasandur, almost perfectly on the particle path to Reykjavík (Fig. 1). The wind-speed was high enough to initiate saltation $\left(U_{t} \sim 8 \mathrm{~m} \mathrm{~s}^{-1}\right)$, that is, over $8 \mathrm{~m} \mathrm{~s}^{-1}$ from 7:00h till 18:00h at FHG and PYK (even higher at STO), and the wind direction close to SE. At a wind speed of 8-10 $\mathrm{m} \mathrm{s}^{-1}$, it takes approximately 3-4 hours for a particle to be passively carried that distance.

Forward modeling using NOAA HYSPLIT confirms that the particle paths of particles originating from Landeyjasandur between 10:00h till 18:00h went directly over Reykjavík on April 28, 2007. The same is true when modeling backwards trajectories from Reykjavík between 12:00h and 20:00h.

$<$ Figure 5>

\subsection{Dust STORM ON JUNE 4, 2008}

The measured PM10 pollution at FHG and GRE on June 4, 2008 (Fig. 6), shows a clear maximum around noon (12:00h) and another in the afternoon (around 18:00h). The data from HEH also shows a similar pattern (Fig. 6), although the $1200 \mathrm{~h}$ peak is quite small. The $\mathrm{PM}_{10}$ values at FHG are usually below $50 \mu \mathrm{g} \mathrm{m}^{-3}$ when due to traffic only, and below $100 \mu \mathrm{g} \mathrm{m}^{-3}$ at GRE.

On an image from the Aqua satellite taken at 13:45h (UTC), a dust storm stemming from Landeyjarsandur does not seem to reach Reykjavík ${ }^{2}$. This agrees well with model runs in HYSPLIT, where the source of the measured $\mathrm{PM}_{10}$ does not seem to come from Landeyjarsandur. Instead particles, arriving at FHG around 12:00h (and possibly 16:00h), originated from ENE to ESE, possibly as far as Skaftárjökull and Tungaárjökull, which are outlet glaciers of Vatnajökull (Fig. 1).

There was an atmospheric low near the country at the time (Fig. 6), so particle paths should be considered only as an indication, as the wind direction may change significantly over short time spans. The wind speed and direction on June 4, 2008, measured at FHG, PYK and STO (Fig. 6), shows that 3 - 5 hours before the peak concentration around noon (Fig. 6), the wind direction was around $100^{\circ}\left(10^{\circ}\right.$ south of east) and the wind speed over $8 \mathrm{~m} \mathrm{~s}^{-1}$ at 8:00h at PYK. There is a change

\footnotetext{
${ }^{2}$ MODIS images at http://rapidfire.sci.gsfc.nasa.gov/ subsets/index2.php?project=firms\& subset=Iceland.2007118.
} 
in wind direction around $14: 00 \mathrm{~h}$, to $\sim 120^{\circ}$, which may explain the reduced levels of $\mathrm{PM}_{10}$ pollution around that time, and possibly indicates a new source for the dust peak around 18:00h, this time from Landeyjarsandur as in the previous example.

$<$ Figure 6>

\subsection{DUST STORMS ON JULY 26 AND 27, 2008}

The measured $\mathrm{PM}_{10}$ pollution at GRE and HEH on July 26 and 27, 2008, shows large peaks at around $15: 30 \mathrm{~h}$ on the 26th (little later at HEH than GRE), and 18:00h on the 27th (Fig. 7).

A MODIS image from the Terra satellite on July 26, 2008, at 13:40h (UTC) clearly shows a dust storm stemming from Landeyjarsandur and blowing over Reykjavík ${ }^{3}$.

The wind speed and direction again suggest Landeyjarsandur as a source area (Figure 7). The wind speed picks up at GRE to over $7 \mathrm{~m} \mathrm{~s}^{-1}$ and the direction changes to $\sim 120^{\circ}$ around 8:00h on the 26th. At PYK the wind speed reaches $10 \mathrm{~m} \mathrm{~s}^{-1}$ around noon on the 26th. On the 27 th the wind starts to pick up around 14:00h, reaching $5 \mathrm{~m} \mathrm{~s}^{-1}$ around 15:00h at GRE, at the same time the wind direction changes to between $140^{\circ}-120^{\circ}$ at GRE, PYK and STO.

$<$ Figure 7>

\section{Estimation of dust source strength}

Based on the measured strength of $\mathrm{PM}_{10}$ pollution in Reykjavík we estimate the quantity of dust transported by wind away from the Landeyjasandur source area seen on the satellite images. To do that we use a simple Gaussian plume model for the distribution of particulate matter. The model assumes a point source, and to estimate the source strength we use equations that relate the horizontal sediment flux to the vertical flux of $\mathrm{PM}_{10}$ material (Draxler et al., 2001; Zender et al., 2003). Our approach is to use the Gaussian plume model to estimate the strength of the source, and compare that to an independently calculated estimate of the source strength.

\footnotetext{
${ }^{3}$ MODIS images at http://rapidfire.sci.gsfc.nasa.gov/subsets/index2.php?project=firms\&subset=Iceland 2008208 . 


\subsection{SOURCE STRENGTH}

To calculate the vertical emission flux of $\mathrm{PM}_{10}$ material, $F$, we used Draxler et al.'s (2001) equation:

$$
F=K \frac{\rho}{g}\left(u_{*}^{2}-u_{t}^{2}\right) u_{*},
$$

where $\rho=1.25 \mathrm{~kg} \mathrm{~m}^{-3}$ is the density of air, $g=9.81 \mathrm{~m} \mathrm{~s}^{-2}$ is the acceleration of gravity, $u *$ is the friction velocity, and $u_{t}$ the threshold friction velocity. $\mathrm{K}$ is a soil surface texture coefficient and is derived from the ratio of vertical $(\mathrm{F})$ to horizontal $\left(\mathrm{Q}_{\text {tot }}\right)$ mass flux. The value of $\mathrm{K}$ for a given threshold velocity is variable (Draxler et al. 2001, their Figure 2; Zender et al. 2003) and also varies with the particle-size distribution of the soil surface. Arnalds et al. (2001; Table 2) quote a mean grain size for surface sediments at Landeyjasandur of $0.41 \mathrm{~mm}$ (medium sand), so for these calculations Gillette et al.'s $(1996,1997)$ value of $\mathrm{K}=1 /\left(0.56 \times 10^{-3}\right)$ for sand was used.

The velocity profile as a function of height above the surface is,

$$
U=\frac{u_{*}}{k} \ln \left(\frac{z}{z_{0}}\right),
$$

where $U$ is velocity at height $z, u *$ is the friction velocity, $k$ is Von Karman's constant, assumed to be 0.41 , and $z_{0}$ is the surface roughness. The drag coefficient $\left(C_{D}\right)$ for saltating conditions $\left(U>U_{t}\right)$ is (Draxler et al. 2001),

$$
\sqrt{C_{D}}=\frac{k}{\ln \left(z / z_{0}\right)}+0.003\left(1-\frac{U_{t}}{U}\right),
$$

where $U_{t}$ is the threshold velocity at height $z$ (Eq. 2) and

$$
u_{*}=\sqrt{C_{D}} U \text {. }
$$

The surface roughness $z_{0}$ and threshold velocity $u_{t}$ for Landeyjasandur is obtained from Arnalds et al. (2001; their Table 3), and are $z_{0}=0.7 \mathrm{~mm}$ and $u_{t}=0.42 \mathrm{~m} \mathrm{~s}^{-1}$.

For the threshold velocity at Landeyjasandur, $u_{t}=0.42 \mathrm{~m} \mathrm{~s}^{-1}$, experiments by Liu et al. (2006) give a grain size $d \sim 0.4 \mathrm{~mm}$ (Fig. 8), which is consistent with the data from Landeyjasandur (Arnalds et al., 2001, their Table 2).

<Figure 8> 
To calculate the source strength for $\mathrm{PM}_{10}$ material we need to multiply $F$ (Eq. 1) with an area $A$, to get the mass flux $S\left(\mathrm{~kg} \mathrm{~s}^{-1}\right)$. The size of the source area $A$ and the wind speed $U$ at the source location are not precisely known, therefore Figure 9 shows the mass flux $F$ as a function of wind speed with the units $\left(\mathrm{kg} \mathrm{km}^{-2} \mathrm{~s}^{-1}\right)$.

$<$ Figure 9>

\subsection{GAUSSIAN PLUME}

There are several versions of the Gaussian plume model. A classic formulation of the concentration, $c$, is the Pasquill-Gifford model,

$$
c=\frac{S}{2 \pi U \sigma_{y} \sigma_{z}} \exp \left(-\frac{y^{2}}{2 \sigma_{y}^{2}}\right)\left[\exp \left(-\frac{(z-H)^{2}}{2 \sigma_{z}^{2}}\right)+\exp \left(-\frac{(z+H)^{2}}{2 \sigma_{z}^{2}}\right)\right],
$$

where

$$
\sigma_{y}=465 x \tan \theta
$$

$\sigma_{z}=a x^{b}$

$\theta=0.0175(12.5-1.086 \ln \mathrm{x})$

$a=61.4$ and $b=0.915$, for Pasquill stability category C. Here $H$ is stack height, $x$ the downwind distance, $y$ perpendicular to $x$ on the ground, and $z$ vertical.

At a distance of $100 \mathrm{~km}$, and Pasquill stability category C, the concentration scales with the source strength $S\left(\mathrm{~kg} \mathrm{~s}^{-1}\right)$ and wind speed $U$ as $c \sim 12.5 S U^{-1} \mu \mathrm{g} \mathrm{m}^{-3}$. The $\mathrm{PM}_{10}$ concentration from a point source, calculated using Eq. 5, is shown in Fig. 10.

Wind speed $U$ of $5-10 \mathrm{~m} \mathrm{~s}^{-1}$ is generally considered necessary for entrainment, and was measured for Icelandic loess/sands (Arnalds et al., 2001). The settling velocity of $10 \mu \mathrm{m}$ particles is about 5 $\mathrm{mm} \mathrm{s}^{-1}$, which yields $18 \mathrm{~m}$ during 3 hours. So settling is not likely to have a large effect, as long as the weather is dry.

A point source of a source strength $S$ of about $200 \mathrm{~kg} \mathrm{~s}^{-1}$ (Fig. 10), gives approximately $200 \mu \mathrm{g} \mathrm{m}^{-3}$ of $\mathrm{PM}_{10}$ pollution in Reykjavík. This means that for a wind speed of $U \sim 12.5 \mathrm{~m} \mathrm{~s}^{-1}$ at the source the source area has to be about $20 \mathrm{~km}^{2}$ to yield $200 \mathrm{~kg} \mathrm{~s}^{-1}$ (Fig. 9). Given this, about 35 tons are blown from each $\mathrm{km}^{2}$ per hour, or $35 \mathrm{~g} \mathrm{~m}^{-2} \mathrm{~h}^{-1}$ of material equal to or smaller than $\mathrm{PM}_{10}$. This is equivalent to $\sim 14-17 \mu \mathrm{m}$ thick layer of $\mathrm{PM}_{10}$ sized material per hour; if the dust has a density of $2500-2000 \mathrm{~kg} \mathrm{~m}^{-3}$. 
$<$ Figure 10>

This value for the source strength is consistent with observations made by Arnalds et al. (2001) of horizontal mass flux of about $200 \mathrm{~kg} \mathrm{~m}^{-1} \mathrm{~h}^{-1}$.

\section{Discussion and conclusions}

The calculation of vertical flux of small, $D_{p}<50 \mu \mathrm{m}$, particles is emperical due to uncertainties about the interaction of these small particles (Kok and Renno, 2006; Shinbrot and Herrmann, 2008). It is calculated as a fraction of the total horizontal flux of particle mass $Q$ (Draxler et al., 2001; Zender et al., 2003),

$F=\alpha Q$

The value of the constant $\alpha$ is quite uncertain (Zender et al., 2003; Draxler et al., 2001), values between $0.1-10.0 \times 10^{-3} \mathrm{~m}^{-1}$ seem possible and a significant determinant is the mass fraction of clay (Marticorena and Bergametti, 1995; Zender et al., 2003). The vertical flux $F$ calculated using Equation (1) is equal to the vertical flux calculated using the method of Marticorena and Bergametti (1995), as outlined in Zender et al. (2003), with sediments dominated by sands and a clay fraction of $2.5 \%$.

Periods of high $\left(>100 \mu \mathrm{g} \mathrm{m}^{-3}, 30\right.$-min values $)$ levels of particulate matter pollution $\left(\mathrm{PM}_{10}\right)$ in Reykjavík are directly related to aeolian sediment transport from the sandur region at Landeyjasandur some $100 \mathrm{~km}$ ESE of the capital city. Landeyjasandur is a coastal area and part of the floodplain of the Markarfljót river which is fed by meltwater from the Mýrdalsjökull and Eyjafjallajökull ice caps. There is a long history of glacial outburst flood events that have affected large areas of the floodplain $\left(40-50 \mathrm{~km}^{2}\right)$ and deposit material that is susceptible to aeolian entrainment (Smith and Dugmore, 2006). Arnalds (2010) identified Landeyjasandur as a major dust plume source area in his recent review of Iceland dust sources and this is confirmed by the events analysed in this paper. Satellite images show that sandur regions around the glaciers in Iceland are prone to aeolian sediment transport and that significant amount of dust is transported to populated areas, like Reykjavík. Dust storms, like those studied here, were important contributors to the 
exceeded daily $50 \mu \mathrm{g} \mathrm{m}^{-3}$ health limit measured at the GRE station in 2007 and 2008.

Given frequent dust storms in Iceland, the impacts of these processes are large both on and off-site (Fig. 5). Further modeling of the concentration and distribution of different PM sizes from source areas might have additional implications. Such information might help quantifying material transported locally and regionally which may impact soil development (e.g. Óskarsson et al., 2004; Gísladóttir et al., 2010) and vegetation (e.g. Gisladottir et al., 2005; Vilmundardóttir et al., 2009). Furthermore, the model might help to quantify the proportions of material transported from the country (e.g. Arnalds and Metúsalemsson, 2004) and quantify pollution in Reykjavík and other urban areas in Iceland from remote dust sources. We can expect an increase in dust storm frequency in Iceland in the future and accordingly increased impact on human health. As a result of climate warming during the $20^{\text {th }}$ century all glaciers in Iceland have retreated (Björnsson and Pálsson, 2008). The receding glaciers leave behind loose sediments with a wide range of particle size from fine silt to coarse sand. Lagoons often form at the terminus of retreating glaciers, and large quantities of glacial sediment are deposited into them. These sandy deposits tend to be finely textured (silt) and when the lagoons drain, they are a major source of aeolian material (Gisladottir et al. 2005, Sugden et al., 2009).

At the global scale, climate change is expected to cause major changes to the ways in which geomorphological processes operate in cold climate environments. Ice retreat triggers new phases of landscape evolution and the influence of glaciers and ice sheets, particularly on fluvial sediment loads, persists long after deglaciation (Dadson and Church, 2005). This influence can be spatially extensive, but is particularly intense in proglacial areas adjacent to ice sheet margins that are directly influenced by fluxes of water and sediment from the ice and which are expected to expand as ice masses contract during the $21^{\text {st }}$ century. Aeolian processes are pervasive in proglacial regions and the magnitude and frequency of aeolian sediment transport events and their impact on glacierised landscapes depends on the extent to which the availability of fine sediment from the ice mass, usually through meltwater, and the winds above the threshold for sediment transport coincide causing, for example, pulsed dust emissions as has been reported from glacial outwash plains in Alaska and Greenland (Bullard and Austin, 2011; Crucius et al. 2011). Climate-driven ice retreat is likely to result in increased mobilisation of fine particles from long-term glacial sediment stores (Hodgkins et al., 2003) - this will deliver greater quantities of fine sediments to the outwash plains than at present, increasing the magnitude and frequency of dust emissions. 


\section{Acknowledgements}

Throstur Thorsteinsson gratefully acknowledges grants from the Energy Research Fund of Orkuveita Reykjavíkur (UOOR) and the Icelandic Road Authority research fund (Vegagerðin). We would also like to thank Gunnhildur Ingibjörg Georgsdóttir who reviewed data for recorded dust storms in 2007 and 2008. 
THORSTEINSSON ET AL.

\section{DUST STORM CONTRIBUTIONS TO AIRBORNE PARTICULATE MATTER IN REYKJAVÍK, ICELAND}

\section{References}

Arnalds O., 2010. Dust sources and deposition of aeolian materials in Iceland. Icelandic Agricultural Sciences, 23, $3-21$.

Arnalds O., Gisladottir F. O., Sigurjonsson H., 2001. Sandy deserts of Iceland: an overview. Journal of Arid Environments 47, 359 - 371. doi:10.1006/jare.2000.0680

Arnalds Ó., Metúsalemsson S., 2004. Sandfok á suðurlandi 5. október 2004 (Dust storm from south Iceland on October 5, 2004). Náttúrufræðingurinn 72 (3-4), 90 - 92.

Baddock M.C., Bullard J.E., Bryant R.G., 2009. Dust source identification using MODIS: a comparison of techniques applied to the Lake Eyre Basin, Australia. Remote Sensing of Environment 113, 1522 - 1528. doi:10.1016/j.rse.2009.03.002

Ballantyne C.K., 2002. Paraglacial geomorphology. Quat. Sci. Rev. 21, 1935 - 2017.

Björnsson H., Pálsson F., 2008. Icelandic glaciers. Jökull 58, 365 - 386.

Borge R., Lumbreras J., Vardoulakis S., Kassomenos P., Rodríguez E., 2007. Analysis of long range transport influences on urban PM10 using two-stage atmospheric trajectory clusters. Atmospheric Environment 41, 4434 - 4450. doi:10.1016/j.atmosenv.2007.01.053

Böðvarsdóttir A. R., 2007. Mælingar á loftmengandi efnum í Reykjavík 2006 (Measurements of air pollutants in Reykjavík 2006). UHR-2007.

Bullard J. E., Austin M. J., 2011. Dust generation on a proglacial floodplain, West Greenland. Aeolian Research, doi:10.1016/j.aeolia.2011.01.002.

Chan Y.C., McTainsh G.H., Leys J.F., McGowan H.A., Tews K., 2005. Influence of the 23 
October 2002 dust storm on the air quality of four Australian cities. Water, air and soil pollution $164,329-348$.

Crucius, J., Schroth, A.W., Gassó, S., Moy, C.M., Levy, R.C., Gatica, M., 2011. Glacial flour dust storms in the Gulf of Alaska: hydrologic and meteorological controls and their importance as a source of bioavailable iron. Geophysical Research Letters, 38, L06602, doi:10.1029/2010GL046573.

Dadson S. J., Church M., 2005. Postglacial topographic evolution of glaciated valleys: a stochastic landscape evolution model. Earth Surface Processes and Landforms, 30, 1387 - 1403. doi: 10.1002/esp.1199

Dijkmans J.W.A., Törnqvist T.E., 1991. Modern periglacial eolian deposits and landforms in the Søndre Strømfjord area, West Greenland and their palaeoenvironmental implications. Meddelelser om Grønland, Geoscience, 25, 7 - 19.

Draxler R. R., Gillette D. A., Kirkpatrick J. S., Heller J., 2001. Estimating PM 10 air concentrations from dust storms in Iraq, Kuwait and Saudi Arabia. Atmospheric Environment, 35, 4315 - 4330. Draxler R.R., Rolph G.D., 2010. HYSPLIT (HYbrid Single-Particle Lagrangian Integrated Trajectory) Model access via NOAA ARL READY Website (http://ready.arl.noaa.gov/HYSPLIT.php). NOAA Air Resources Laboratory, Silver Spring, MD.

Dugmore A. J., Gísladóttir G., Simpson I. A., Newton A., 2009. Conceptual models of 1200 years of Icelandic soil erosion reconstructed using tephrochronology. Journal of the North Atlantic, 2, $1-18$.

Gassó S., Stein A.F., 2007. Does dust from Patagonia reach the sub-Antarctic Atlantic Ocean. Geophysical Research Letters, 34, doi:10.1029/2006GL027693.

Gathorn-Hardy F.J., Erlendsson E., Langton P., Edwards K.J., 2009. Lake sediment evidence for late-Holocene climate change and landscape erosion in western Iceland. Journal of Paleolimnology. 42, 413 - 426. doi: 10.1007/s10933-008-9285-4.

Geirsdóttir Á., Miller G.H., Pórðarson P., Ólafsdóttir K., 2009. A 2000 year record of climate variations reconstructed from Haukadalsvatn, West-Iceland. Journal of Paleolimnology 41, 95 - 
115. doi: 10.1007/s10933-008-9253-z.

Gillette D., Herbert G., Stockton P., Owen P., 1996. Causes of the fetch effect in wind erosion. Earth Surface Processes and Landforms 21, 641 - 659. doi: 10.1002/(SICI)1096-9837(199607)

Gillette D.A., Fryrear D.W., Gill T.E., Ley T., Cahill T.A., Gearhart E.A., 1997. Relation of vertical flux of particles smaller than $10 \mu \mathrm{m}$ to total aeolian horizontal mass flux at Owens Lake. Journal of Geophysical Research, 102, 26009 - 26015. doi:10.1029/97JD02252

Gisladottir F. O., Arnalds O., Gisladottir G., 2005. The effect of landscape and retreating glaciers on wind erosion in south Iceland. Land Degradation and Development, 16, 177 - 187. doi: 10.1002/ldr.645

Gísladóttir G., Erlendsson E., Lal R., Bigham J., 2010. Erosional effects on terrestrial resources over the last millennium in Reykjanes, southwest Iceland. Quaternary Research 73, 20 - 32. doi:10.1016/j.yqres.2009.09.007.

Goudie A. S., 2009. Dust storms: Recent developments. Journal of Environmental Management, 90, 89 - 94. doi:10.1016/j.jenvman.2008.07.007

Griffin D. W., Kellogg C. A., 2004. Dust storms and their impact on ocean and human health: Dust in earth's atmosphere. EcoHealth, 1, 284 - 295. doi: 10.1007/s10393-004-0120-8

Guðbergsson G., 1996. The influence of human habitation on soil and vegetation in three counties in North-Iceland. Icelandic Agricultural Science, 10, 31 - 89.

Hodgkins R., Cooper R., Wadham J., Tranter M., 2003. Suspended sediment fluxes in a highArctic glacierised catchment: implications for fluvial sediment storage. Sedimentary Geology 162, 105 - 117. doi:10.1016/S0037-0738(03)00218-5

Hodson A.J., Ferguson R.I., 1999. Fluvial suspended sediment transport from cold and warmbased glaciers in Svalbard. Earth Surface Processes and Landforms, 24, 957 - 974. doi: 10.1002/(SICI)1096-9837(199910)

Hope A.S., Fleming J.B., Stow D.A., Aguado E., 1991. Tussock tundra albedos on the north 
slope of Alaska: effects of illumination, vegetation composition and dust deposition. Journal of Applied Meteorology, 30, $1200-1206$.

Jackson M. G., Oskarsson N., Tronnes R. G., McManus J. F., Opposed D. W., Gronvold K., Hart S. R., Sachs J.P., 2005. Holocene loess deposition in Iceland: evidence for millennial-scale atmosphere-ocean coupling in the North Atlantic. Geology, 33, 6, 509 - 512. doi:10.1130/G21489.1

Jickells T.D. and 18 others, 2005. Global iron connections between desert dust, ocean biogeochemistry and climate. Science, 308, $67-71$.

Jóhannsson P., 2007. Svifryksmengun í Reykjavík (Particulate matter pollution in Reykjavik). M. Sc. Thesis, University of Iceland.

Karaca F., Anil I., Alagha O., 2009. Long range potential source contributions of episodic aerosol events to PM10 profile of a megacity. Atmospheric Environment, 43, 5713 - 5722. doi:10.1016/j.atmosenv.2009.08.005

Kok J. F., Renno N. O., 2006. Enhancement of the emission of mineral dust aerosols by electric forces. Geophysical Research Letters, 33, L19S10.

Krzyzanowski M., Kuna-Dibbert B., Schneider J. (editors), 2005. Health Effects of Transportrelated Air Pollution. WHO Press.

Liu X., Dong Z., Wang X., 2006. Wind tunnel modeling and measurements of the flux of windblown sand. Journal of Arid Environments, 66, 657 - 672. doi:10.1016/j.jaridenv.2005.11.010

McGowan H., Clark A., 2008. Identification of dust transport pathways from Lake Eyre, Australia using HYSPLIT. Atmospheric Environment, 42, 6915 - 6925. doi:10.1016/j.atmosenv.2008.05.053

McTainsh G. H., Strong C.S., 2007. The role of aeolian dust in ecosystems. Geomorphology, 89, 1-2, 39 - 54. doi:10.1016/j.geomorph.2006.07.028

Marticorena B., Bergametti G., 1995. Modeling the atmospheric dust cycle: 1. Design of a soil- 
derived dust emission scheme. Journal of Geophysical Research, 100 (D8), 16415 - 16430. doi:10.1029/95JD00690

Marx S.K., McGowan H.A., 2005. Dust transportation and deposition in a superhumid environment, West Coast, South Island, New Zealand. Catena, 59, 147 - 171. doi:10.1016/j.catena.2004.06.005

Nickling W.G., 1978. Eolian sediment transport during dust storms: Slims River Valley, Yukon Territory. Canadian Journal of Earth Sciences, 15, 1069 - 1084.

Ólafsdóttir R., Guðmundsson H., 2002. Holocene land degradation and climatic change in northeast Iceland. The Holocene 12, 159 - 167. doi:10.1191/0959683602hl531rp

Orwin J.F., Lamoureux S.F., Warburton J., Beylich A., 2010. A framework for characterizing fluvial sediment fluxes from source to sink in cold environments. Geografiska Annaler, 92 A(2), 155 - 176. doi: 10.1111/j.1468-0459.2010.00387.x

Óskarsson H., Arnalds Ó., Gudmundsson J., Gudbergsson G., 2004. Organic carbon in Icelandic Andosols: geographical variation and impact of erosion. Catena 56, 225 - 238. doi:10.1016/j.catena.2003.10.013.

Ovadnevaite J., Ceburnis D., Plauskaite-Sukiene K., Modini R., Dupuy R., Rimselyte Il, Ramonet M., Kvietjus K., Ristoski Z., Berresheim H., O’Dowd C.D., 2009. Volcanic sulphate and arctic dust plumes over the North Atlantic Ocean. Atmospheric Environments, doi:10.1016/j.atmosenv2009.07.007.

Pálsson S., Harðardóttir J., Vigfússon G. H., Snorrason Á., 2000. Reassessment of suspended load of river Jökulsá á Dal at Hjarðarhagi. Reykjavik, Orkustofnun (National Energy Authority), Report OS-2000/070.

Prospero J. P., Ginoux P., Torres O., Nicholson S. E., Gill T. E., 2002. Environmental characterisation of global sources of atmospheric soil dust identified with the Nimbus 7 Total Ozone Mapping Spectrometer (TOMS) absorbing aerosol product. Reviews of Geophysics, 40, 21 - 31. doi:10.1029/2000RG000095 
Prospero J.P., Arnalds O., Olafsson H, Bullard J.E., Hodgkins R., 2008. Iceland dust storms linked to glacial outwash deposits and to sub-glacial flood (jökulhlaup) events. Eos Trans. AGU 89 (53) Fall Meeting Supplementary. Abstract A13E-08.

Rivera N.I.R., Gill T.E., Gebhart K.A., Hand J.L., Bleiweiss M.P., Fitzgerald R.M., 2009. Wind modelling of Chihuahuan Desert dust outbreaks. Atmospheric Environment, 43, 347 - 354. doi:10.1016/j.atmosenv.2008.09.069

Schepanski K., Tegen I., Laurent B., Heinold B., Macke A., 2007. A new Saharan dust source activation frequency map derived from MSG-SEVIRI IR-channels. Geophysical Research Letters, 34, L18803, doi:10.1029/2007/GL030168.

Shinbrot T., Herrmann H. J., 2008. Static in motion (news \& views). Nature, 451, 773 - 774. doi:10.1038/451773a

Sigurðsson O., 1998. Glacier variations in Iceland 1930 - 1995: from the database of the Iceland Glaciological Society. Jökull, 45, 3 - 25.

Smith, K.T. and Dugmore, A.J., 2006. Jökulhlaups circa Landnám: mid- to late first millenium AD floods in south Iceland and their implications for landscapes of settlement. Geografiska Annaler, 88 A (2), 165 - 176. doi: 10.1111/j.0435-3676.2006.00292.x

Song Z., Wang J., Wang S., 2007. Quantitative classification of northeast Asian dust events. Journal of Geophysical Research, 112 (D04211), doi:10.1029/2006JD007048.

Stout J.E., 2010. Diurnal patterns of blowing sand. Earth Surface Processes and Landforms, 35, 3, 314 - 318. doi: 10.1002/esp.1919

Sugden D.E., McCulloch R.D., Bory A. J-M, Hein A.S., 2009. Influence of Patagonian glaciers on Antarctic dust deposition during the last glacial period. Nature Geosciences, doi:10.1038/NGEO474.

Tanaka T.Y., Chiba M. 2006. A numerical study of the contributions of dust source regions to the global dust budget. Global Planetary Change 52, 88 - 104. doi:10.1016/j.gloplacha.2006.02.002 
Tegen I., Zender C.S., Miller R., 2004: Quantifying mineral dust mass budgets: terminology, constraints, and current estimates. Eos, 85(48), 509 - 512. doi:10.1029/2004EO480002

Vilmundardóttir O.K., Magnússon B., Gísladóttir G., Magnússon S.M., 2009. Gróðurframvinda í áfoksgeira í mólendi við Blöndulón (Effect of sand burial on alpine heathland vegetation at Blöndulón Reservoir, Iceland). Náttúrufræðingurinn, 78 (3-4), 125 - 137.

Wang H., Shooter D., 2005. Source apportionment of fine and coarse atmospheric particles in Auckland, New Zealand. Science of the Total Environment, 340, $189-198$. doi:10.1016/j.scitotenv.2004.08.017

Wiggs G.F.S., Baird A.J., Atherton R.J., 2004. The dynamic effects of moisture on the entrainment and transport of sand by wind. Geomorphology, 59, $13-30$. doi:10.1016/j.geomorph.2003.09.002

Zender C. S., Bian H., Newman D., 2003. Mineral Dust Entrainment and Deposition (DEAD) model: Description and 1990s dust climatology. Journal of Geophysical Research, 108 (D14), 4416. doi:10.1029/2002JD002775 
THORSTEINSSON ET AL.

\section{DUST STORM CONTRIBUTIONS TO AIRBORNE PARTICULATE MATTER IN REYKJAVÍK, ICELAND}

FIGURES

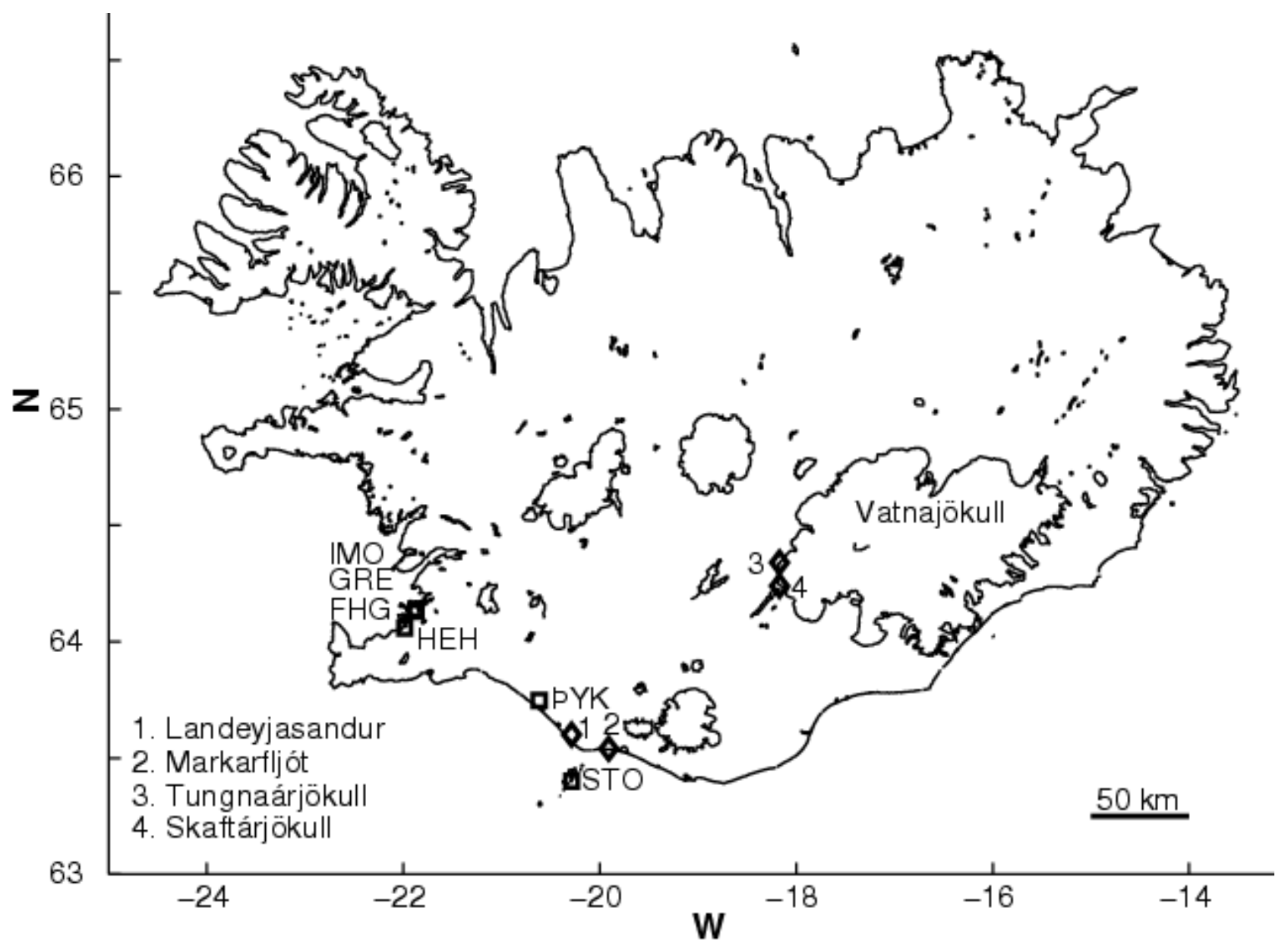

Figure 1. Map of Iceland showing the location of $\mathrm{PM}_{10}$ measurement stations in the Reykjavík area, GRE, FHG and HEH, and the weather stations used IMO (Reykjavík), PYK and STO in this study. Locations mentioned in the text are indicated. 
Thorsteinsson et al. Dust storm contributions to airborne PM in Reykjavík, Iceland.
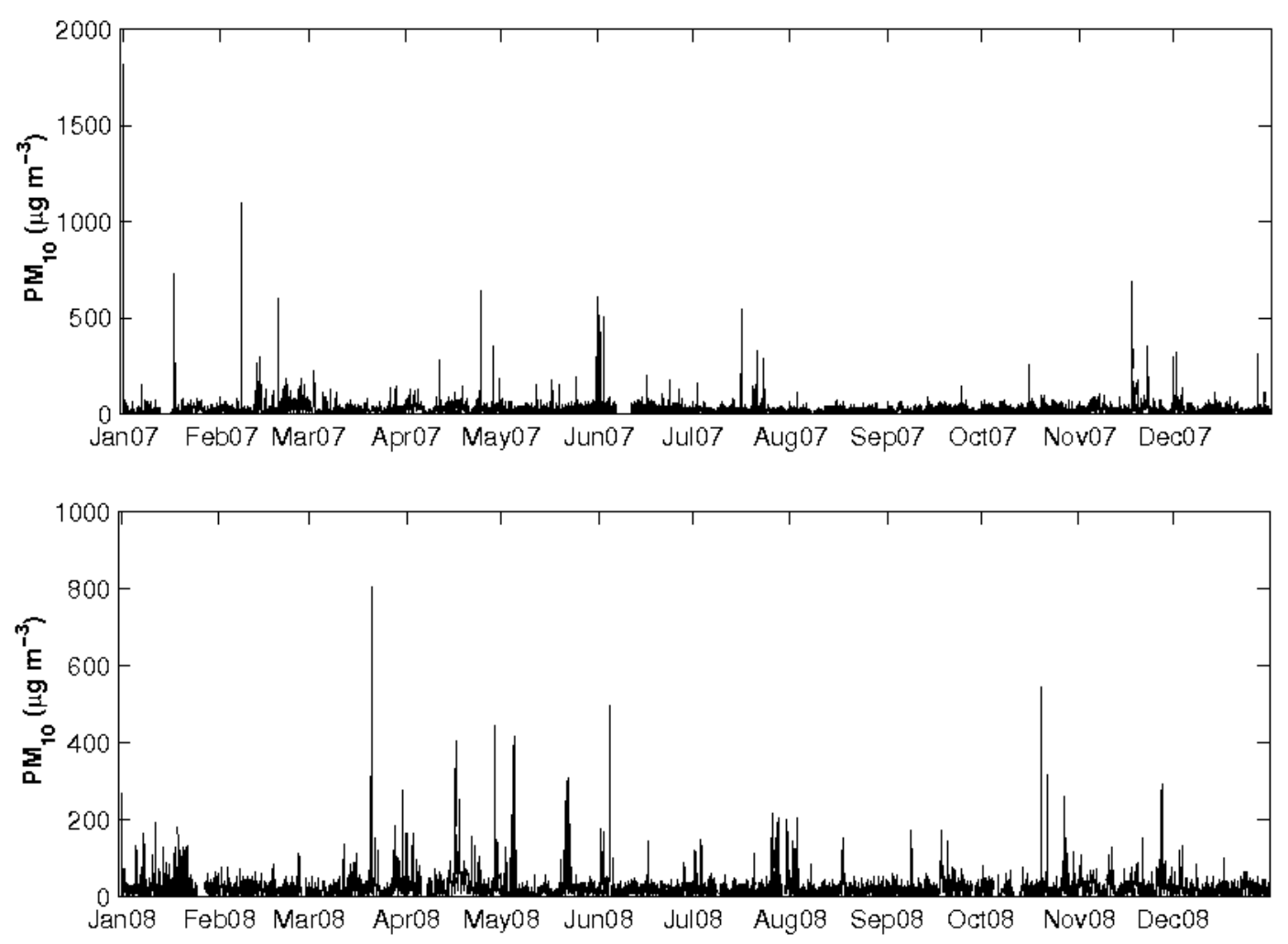

Figure 2. $\mathrm{PM}_{10}$ pollution levels at GRE-station for the years 2007 and 2008 (30-min values). 


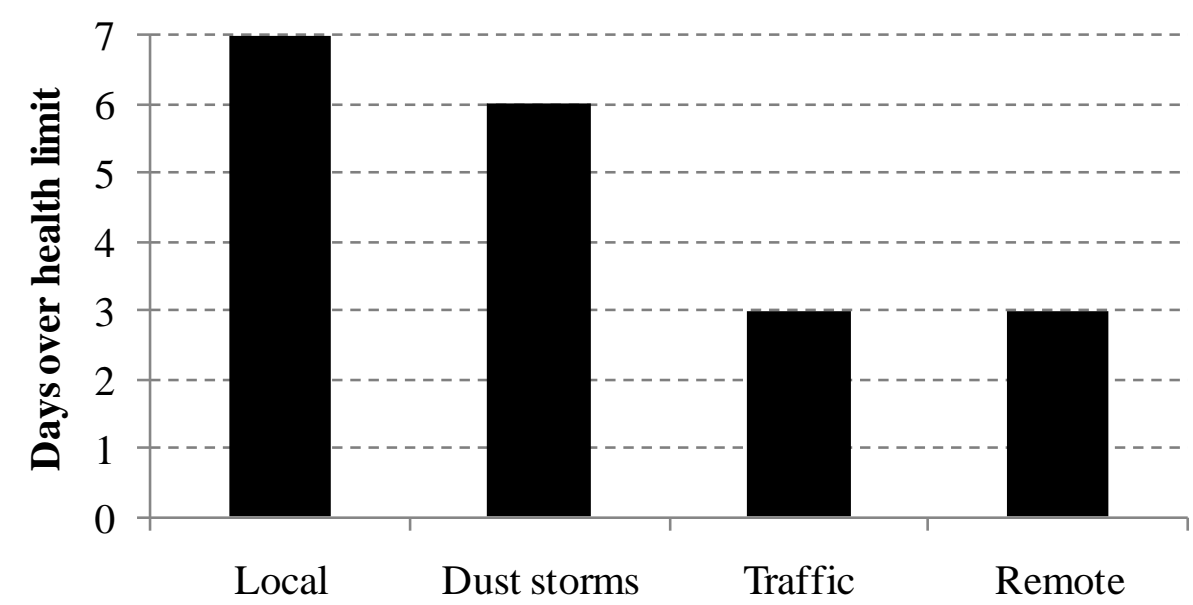

Figure 3. Sources of $\mathrm{PM}_{10}$ material during days that exceeded the health limit in 2008 at GREstation. 


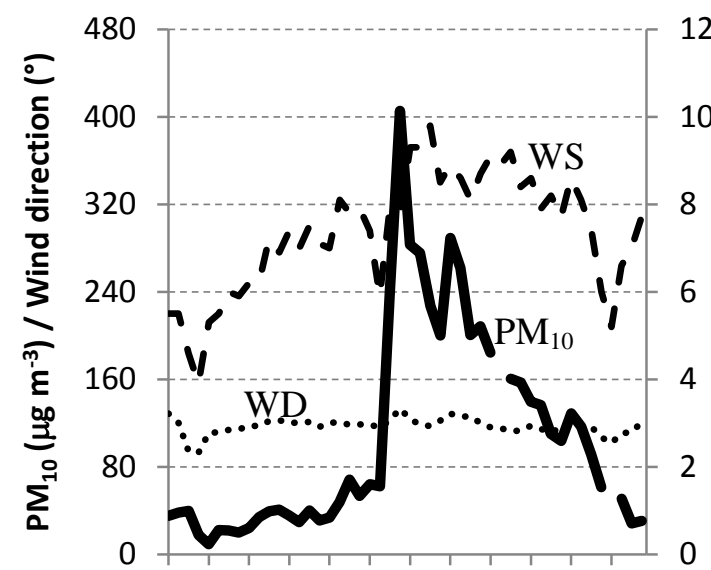

$\begin{array}{llllll}0 & 2 & 4 & 6 & 8 & 10121416182022\end{array}$

16 April 2008

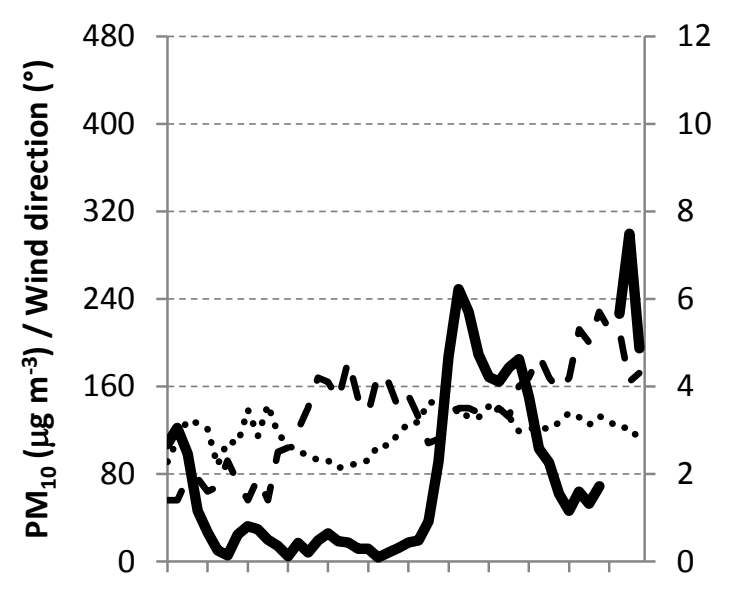

$0 \begin{array}{llllll}0 & 4 & 6 & 8 & 10121416182022\end{array}$

21 May 2008

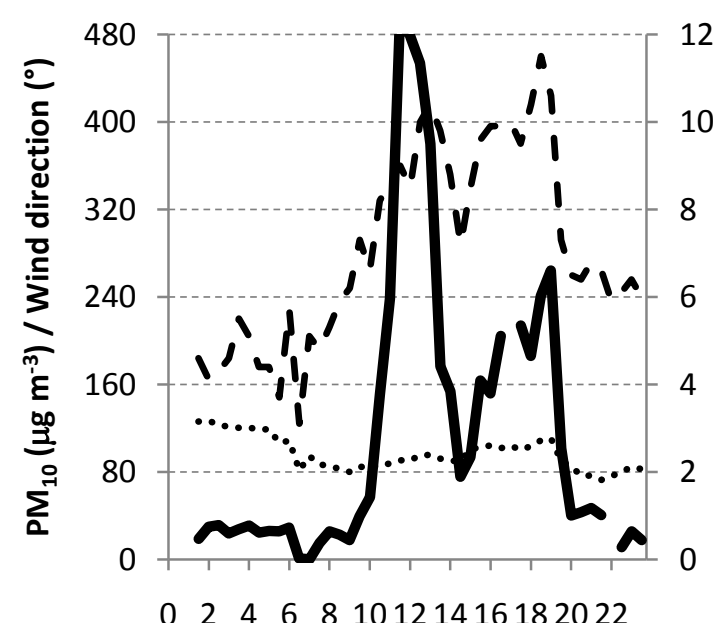

4 June 2008

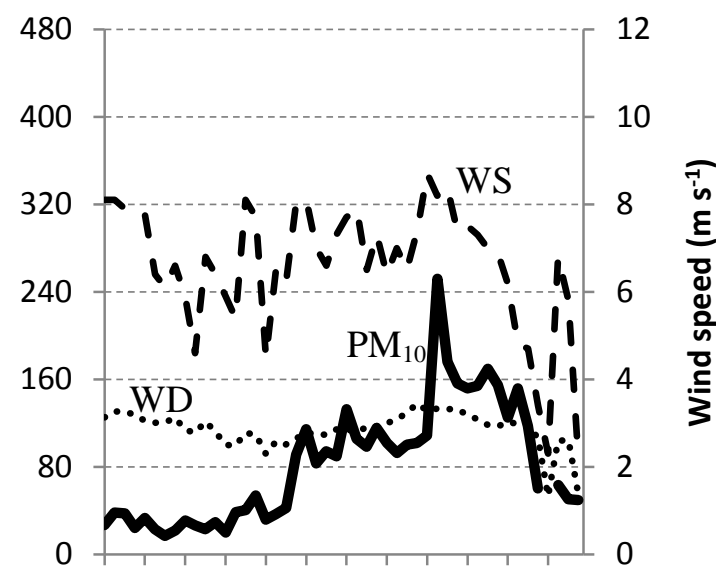

$0 \begin{array}{llllll}0 & 2 & 4 & 6 & 8 & 10121416182022\end{array}$

17 April 2008

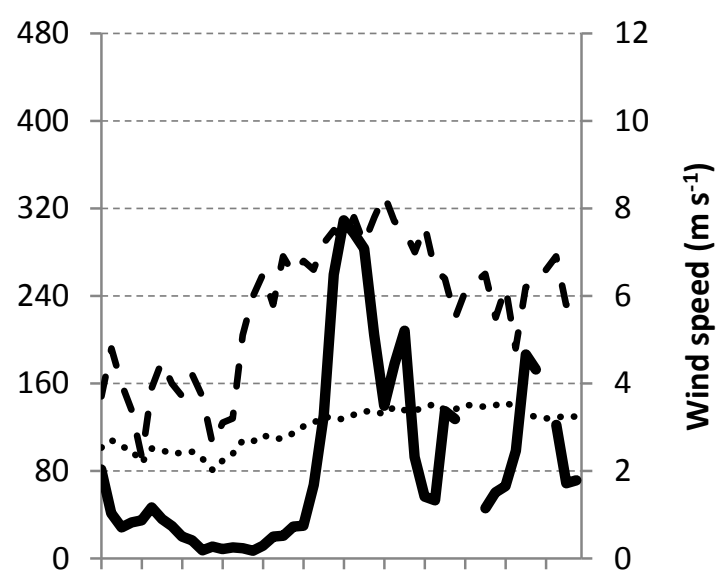

$0 \begin{array}{llllll}0 & 2 & 4 & 6 & 8 & 10121416182022\end{array}$

22 May 2008

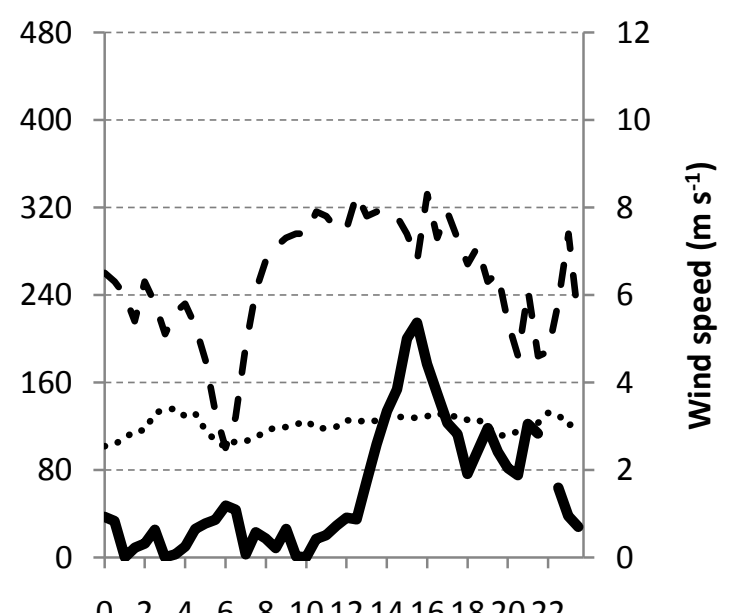

26 July 2008

Figure 4. $\mathrm{PM}_{10}$ (thick lines), wind speed (dashed lines) and wind direction (dotted lines) measured at the GRE-station during days of dust storms in 2008. 

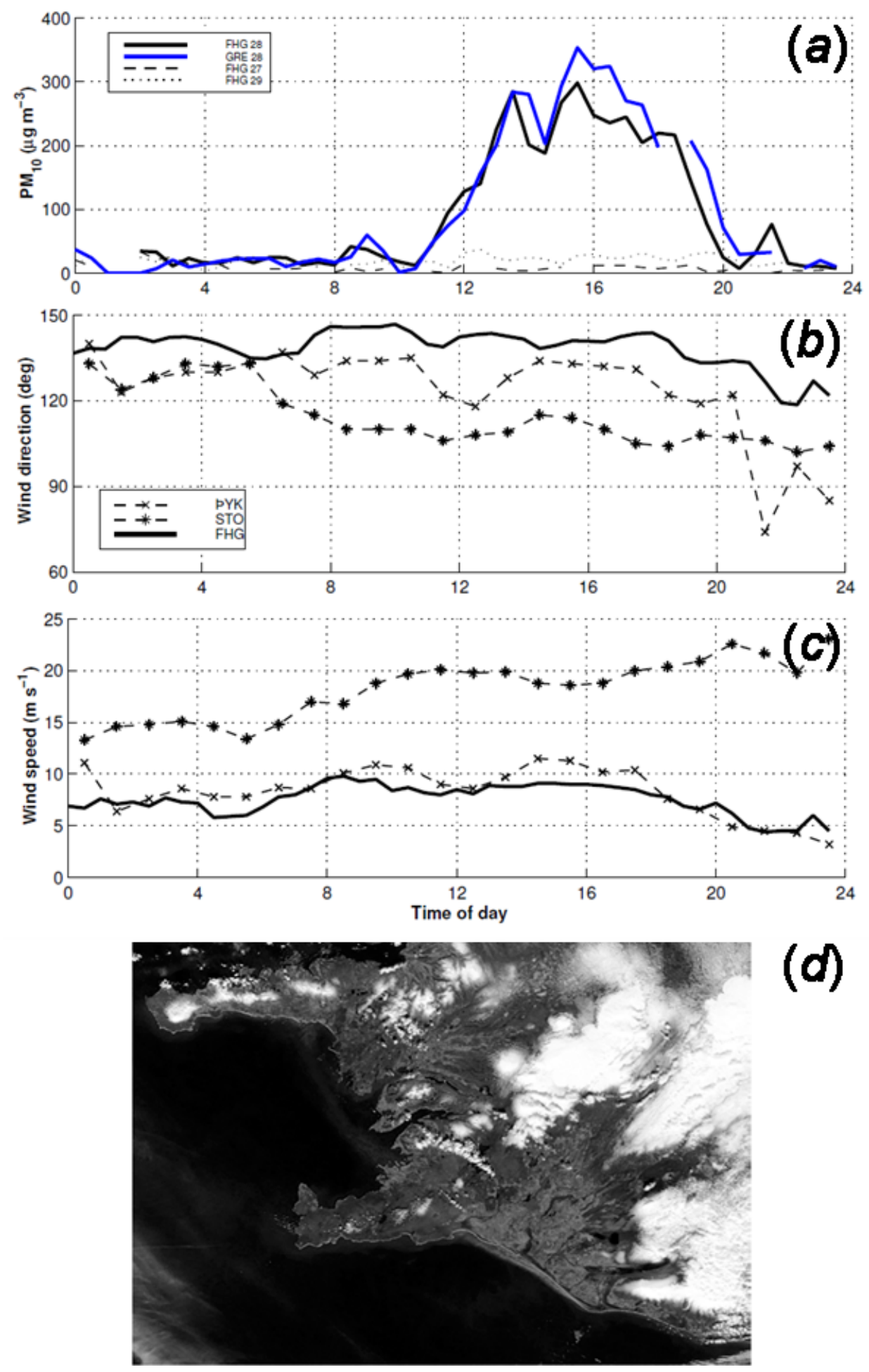

(d)

Figure 5. Summary data for dust event on 28 April, 2007. (a) $\mathrm{PM}_{10}$ (30-min values) measured at FHG (April 27 - 29) and GRE, (b) wind direction and (c) wind speed measured on April 28, 2007 at FHG (solid line), STO (star-dashed line), and PYK (x-dashed line). (d) MODIS Aqua image 13:45 (local time) showing dust blowing from Landeyjasandur and Markarfljót (on the coast just north of STO; Fig. 1) towards Reykjavík on April 28, 2007. Image courtesy of MODIS Rapid Response System at NASA/GSFC. 

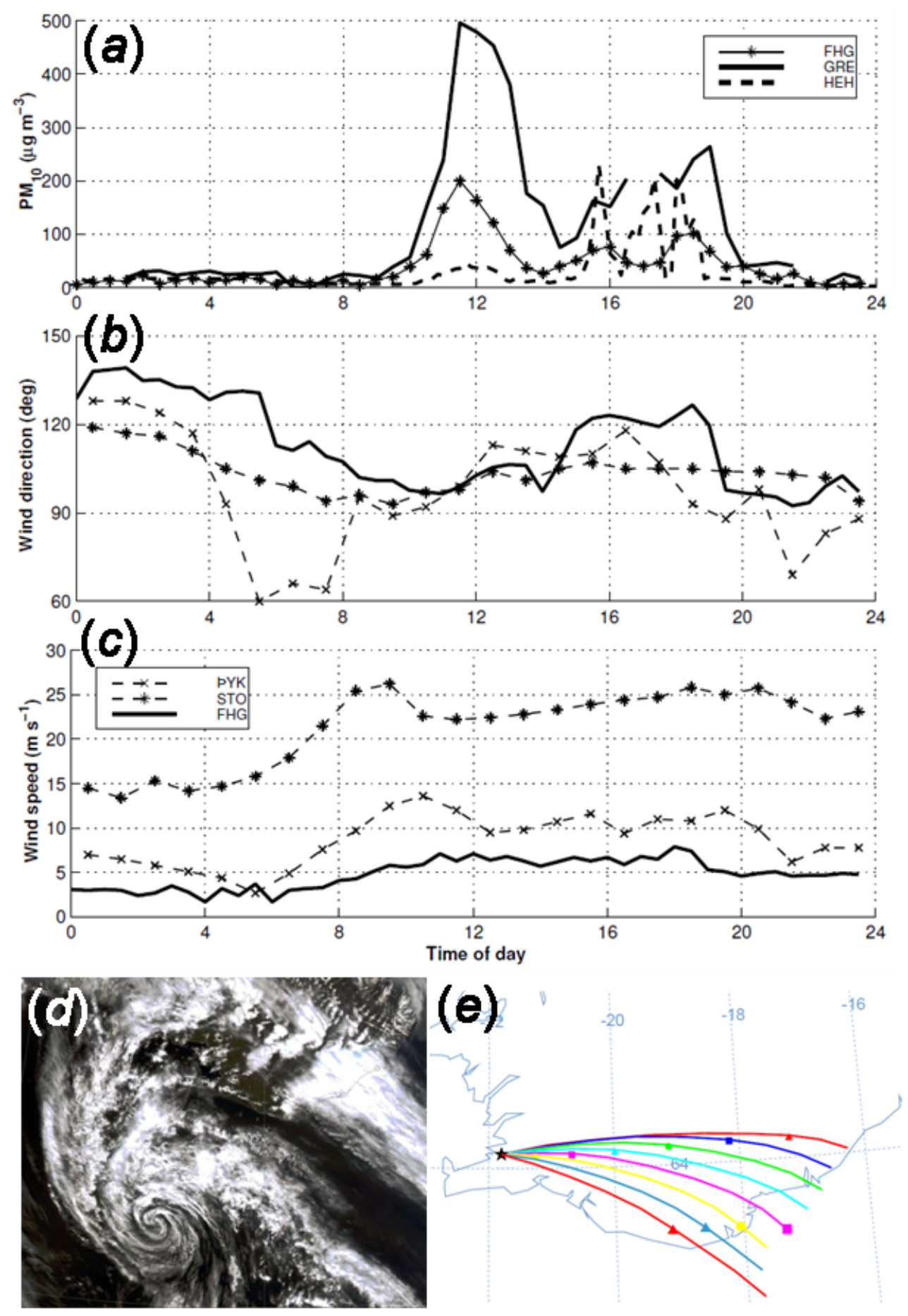

Figure 6. Summary data for dust event on 4 June 2008. (a) $\mathrm{PM}_{10}$ measured at FHG (stars), GRE (solid line), and HEH (dashed line), (b) wind direction and (c) wind speed on June 4, 2008, measured at FHG (solid line), STO (star-dashed line), and PYK (x-dashed line); (d) MODIS image from 14:17 on June 4, 2008, showing the low south of Iceland responsible for the wind that caused the dust storm that day; (e) NOAA HYSPLIT runs (bottom right) for June 4, 2008, showing particle paths for backward trajectories ending in Reykjavík at 12:00 UTC. 

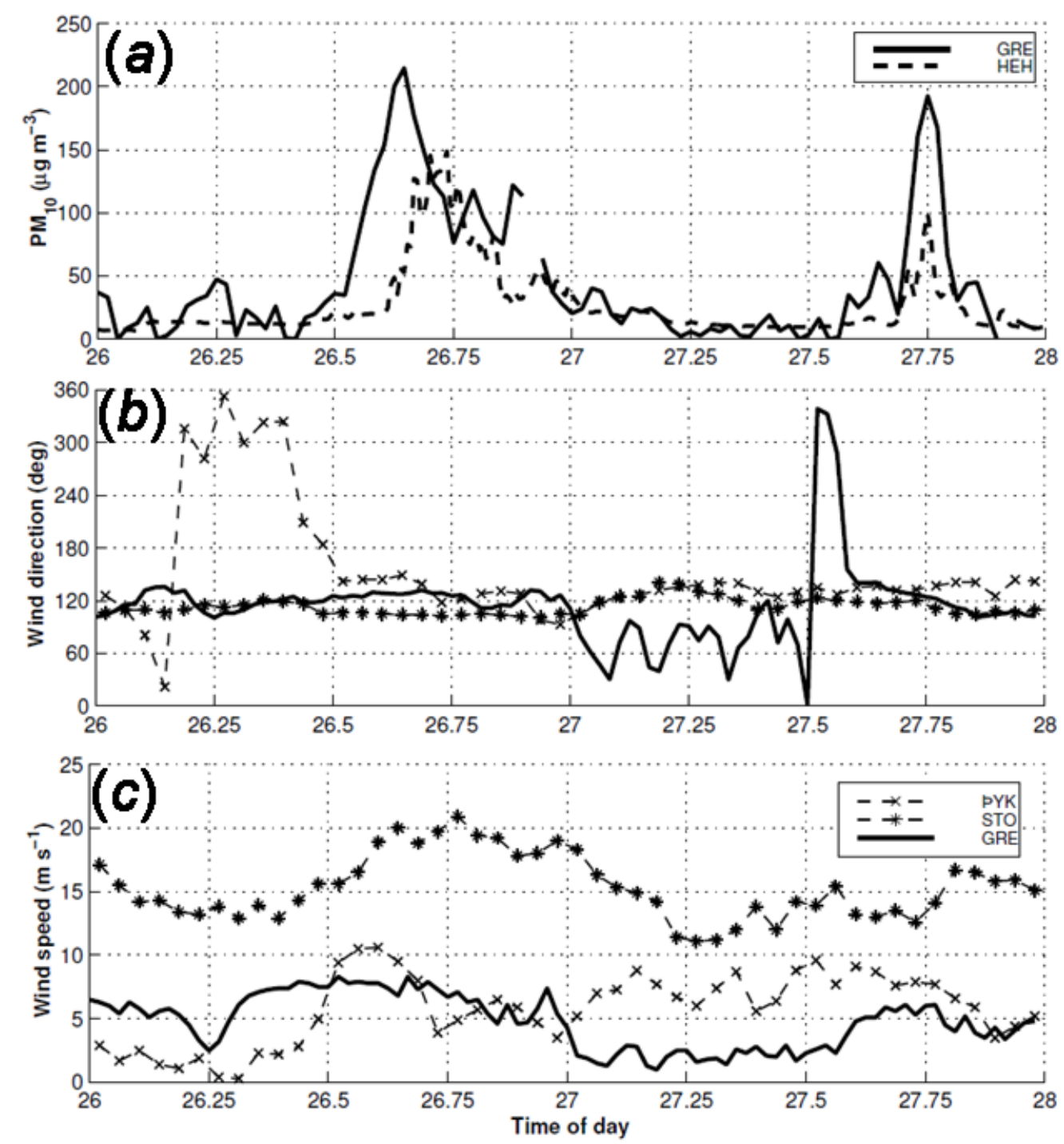

Figure 7. Summary data for dust event on 26-27 July 2008. (a) $\mathrm{PM}_{10}$ measured at GRE (30-min values; solid line) and HEH (10-min values; dashed line), (b) wind direction and (c) wind speed on July 26 and 27, 2008, measured at GRE (solid line), STO (star-dashed line), and PYK (x-dashed line). 


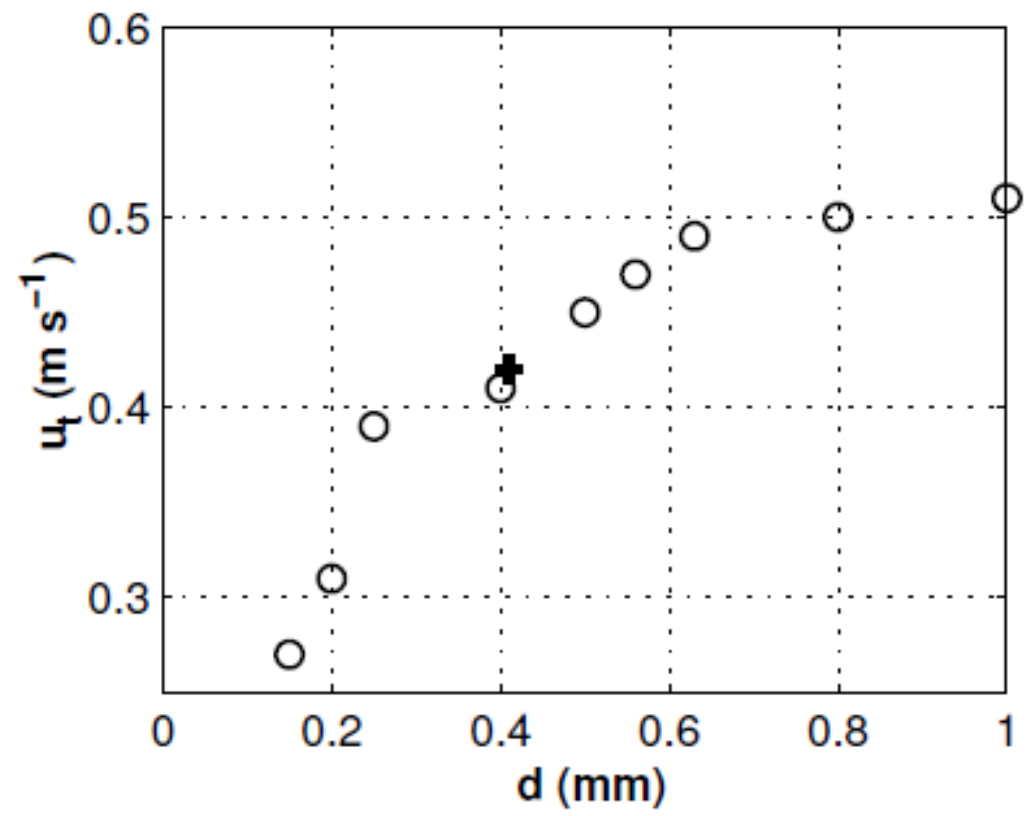

Figure 8. Threshold velocity $u_{t}$ as a function of grain size $d$ (Liu et al., 2006, Table 2). The value for Landeyjasandur (Arnalds et al., 2001, Table 2) is marked by a '+'. 


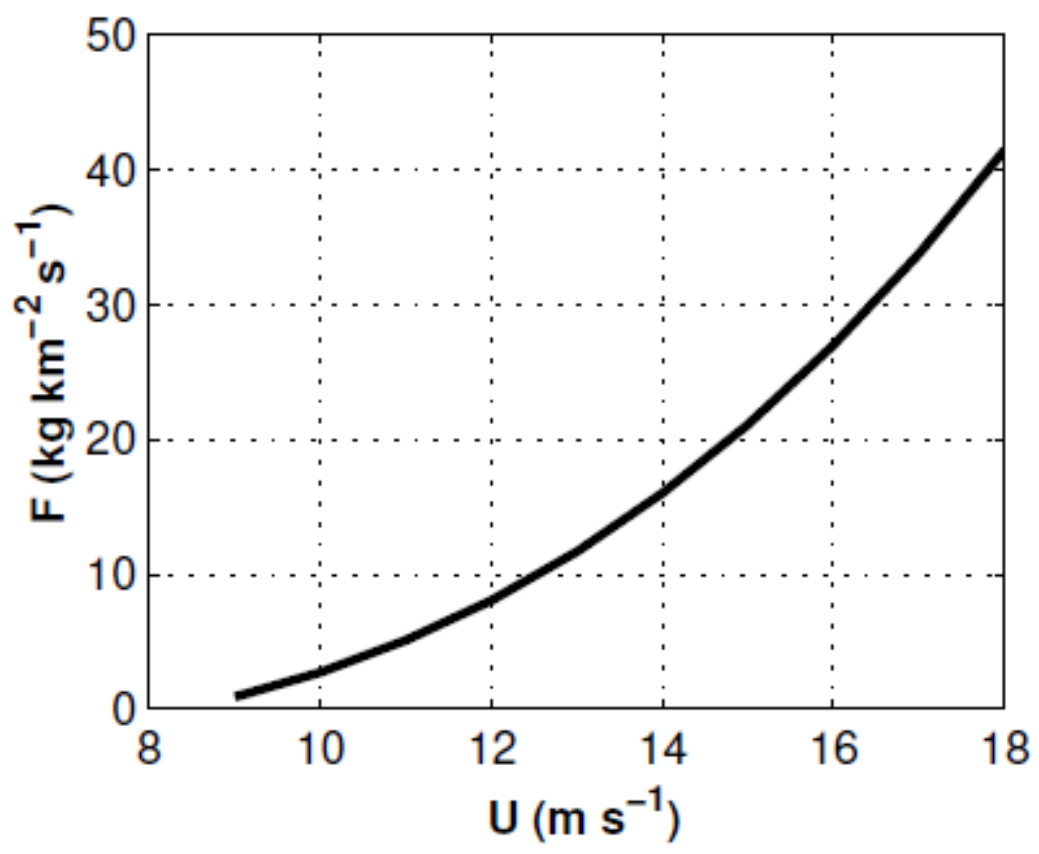

Figure 9. Calculated vertical mass flux of $\mathrm{PM}_{10}$ material, $F\left(\mathrm{~kg} \mathrm{~km}^{-2} \mathrm{~s}^{-1}\right)$ (Eq. 1), as a function of wind speed at $2 \mathrm{~m}$ elevation. Here $\alpha=0.2 \times 10^{-3} \mathrm{~m}^{-1}, z_{0}=0.7 \mathrm{~mm}$, and $u_{t}=0.42 \mathrm{~m} \mathrm{~s}^{-1}$. 
Thorsteinsson et al. Dust storm contributions to airborne PM in Reykjavík, Iceland.

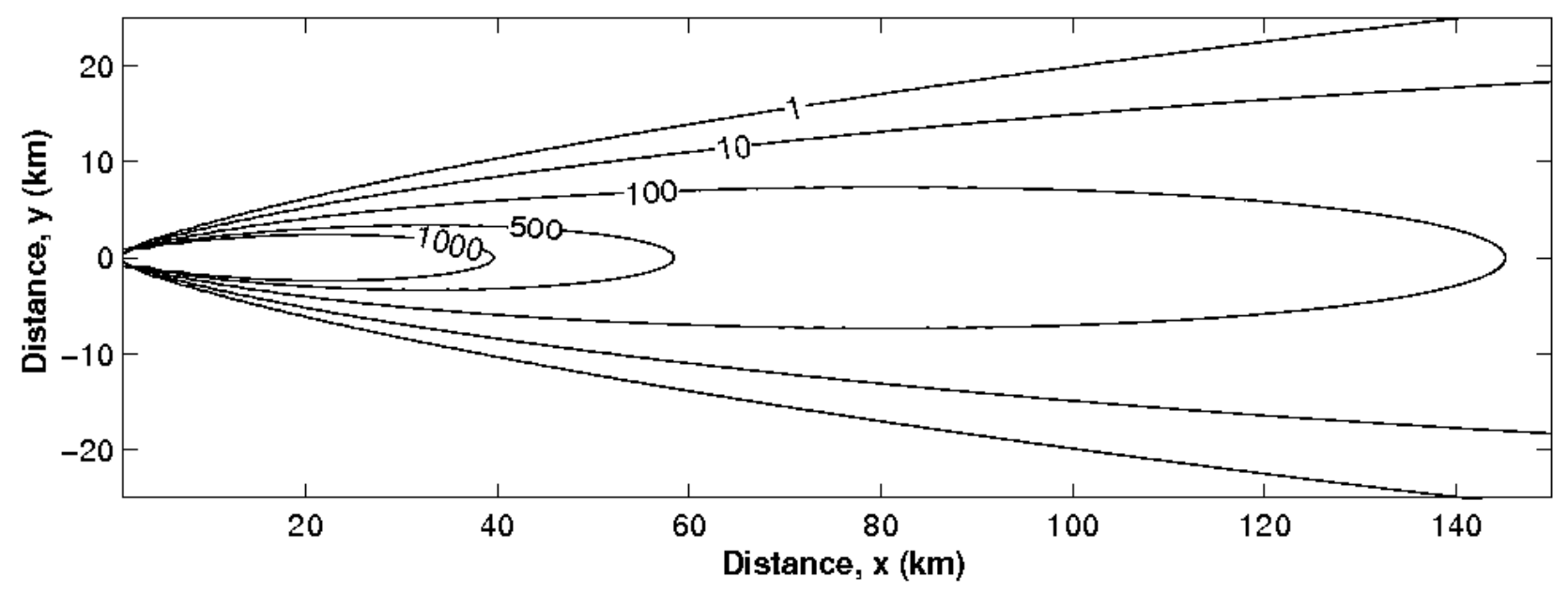

Figure 10. Concentration $\left(\mu \mathrm{g} \mathrm{m}^{-3}\right)$ as a function of distance from a point source, where the wind speed $U$ is $10 \mathrm{~m} \mathrm{~s}^{-1}$, and the source strength $S$ is $200 \mathrm{~kg} \mathrm{~s}^{-1}$. 